\title{
KADERISASI PARTAI NASDEM DALAM MENGHADAPI PEMILU LEGISLATIF 2014 DI KABUPATEN MAROS
}

\author{
Nurazizah $^{1}$, Jaelan Usman ${ }^{2}$, Andi Luhur Prianto ${ }^{1}$ \\ ${ }^{1}$ Program Studi Ilmu Pemerintahan Fakultas Ilmu Sosial dan Ilmu Politik \\ Universitas Muhammadiyah Makassar \\ Jl Sultan Alauddin No 259 Makassar 90221 \\ Telp. 0411-866972 ext. 107. Fax. 0411-8655888 \\ nur azizah92@yahoo.co.id luhur@unismuh.ac.id \\ 2 Program Studi Ilmu Adminitrasi Negara Fakultas Ilmu Sosial dan Ilmu Politik \\ Universitas Muhammadiyah Makassar \\ Jl Sultan Alauddin No 259 Makassar 90221 \\ Telp. 0411-866972 ext. 107. Fax. 0411-8655888 \\ jaelani usman@yahoo.com
}

\begin{abstract}
This study aims to determine the recruitment of party politics Nasdem in determining its cadres in anticipation of the legislative elections of 2014. This study used a qualitative research approach is descriptive analysis with analytical and institutional approaches. Data collection techniques used were interviews, observation, and documentation. Interviews and observations conducted on the research informants while documentation is used to find out the extent of truth of the data obtained. The results of the field studies showed that the patterns of political recruitment of legislative candidates used in the Nasdem Party DPD Maros using open recruitment patterns. Recruitment pattern is expected to create a cadre of candidates and legislative candidates qualified. So that the quality of legislative candidates is expected to be a cadre get mass.
\end{abstract}

Keywords: political recruitment, institutionalization, legislative elections

\begin{abstract}
ABSTRAK
Penelitian ini bertujuan untuk mengetahui proses rekrutmen politik partai Nasdem dalam menentukan kadernya sehingga siap menghadapi pemilu legislatif 2014. Penelitian ini menggunakan penelitian kualitatif deskriftif analisis dengan pendekatan analisis dan pendekatan institusional. Tekhnik pengumpulan data yang digunakan yaitu wawancara, observasi, dan dokumentasi. Wawancara langsung dan observasi dilakukan pada informan penelitian sedangkan dokumentasi digunakan untuk mencari tahu sejauhmana kebenaran dari data yang didapatkan. Hasil penelitian dilapangan menunjukkan bahwa pola rekrutmen politik calon anggota legislatif yang digunakan pada DPD Partai Nasdem Kabupaten Maros menggunakan pola rekrutmen terbuka. Pola rekrutmen ini diharapkan mampu menciptakan calon kader dan calon anggota legislatif yang berkualitas. Sehingga calon anggota legislatif yang berkualitas ini diharapkan mampu menjadi kader pendulang suara.
\end{abstract}

Kata kunci: rekrutmen politik, institusionalisasi, pemilu legislatif 


\section{A. PENDAHULUAN}

Partai politik hadir di tengahtengah masyarakat bertujuan untuk mencari dan mempertahankan kekuasaan guna mewujudkan programprogram yang disusun berdasarkan ideologi tertentu. Dalam pembentukan partai politik diatur dalam UU No.2 Tahun 2011 pasal 2 ayat 1 mengenai Pembentukan Partai Politik yang bunyinya "Partai Politik didirikan dan dibentuk oleh paling sedikit 50 orang warga negara Indonesia yang telah berusia 21 tahun dengan akta notaris". Cara yang digunakan oleh suatu partai politik dalam sistem demokrasi untuk mendapatkan dan mempertahankan kekuasaan ialah ikut serta dalam pemilihan umum (Surbakti,2010:149). Partai politik agar memperoleh eksistensi dalam sistem politik, partai politik harus bersaing dalam pemilihan umum untuk memperoleh suara dari masyarakat dan mendapat kursi di parlemen.

Rekrutmen politik memegang peranan penting dalam sistem politik suatu negara. Karena proses ini menentukan orang-orang yang akan menjalankan fungsi-fungsi sistem politik negara itu melalui lembaga-lembaga yang ada. Rekrutmen politik diatur dalam UU No.2 Tahun 2011 pasal 29 ayat 1 yang berbunyi "Partai politik melakukan Rekrutmen terhadap warga negara Indonesia untuk menjadi anggota partai politik, bakal calon anggota Dewan Perwakilan Rakyat dan Dewan Perwakilan Rakyat Daerah, bakal calon Presiden dan Wakil Presiden, dan calon Kepala Daerah dan Wakil Kepala Daerah. Oleh karena itu, tercapai tidaknya tujuan suatu sistem politik yang baik tergantung pada kualitas rekrutmen politik. Kehadiran suatu partai politik dapat dilihat dari kemampuan partai tersebut melaksanakan fungsinya. Salah satu fungsi yang terpenting yang dimiliki partai politik adalah fungsi rekrutmen politik.

Dibalik hal itu, ormas Nasional Demokrat "menjelma" menjadi partai nasional demokrat (Partai Nasdem) pada tanggal 26 Juli 2011. Partai Nasdem resmi sebagai salah satu partai yang akan bertarung pada Pemilu 2014. Deklarasi partai Nasdem dilakukan di hotel mercure ancol Jakarta, yang disiarkan langsung oleh MetroTV. Sekretariat jenderal partai Nasdem, Ahmad Rofiq mengatakan, deklarasi itu merupakan salah satu cara untuk melakukan gerakan perubahan menuju restorasi cita-cita Republik Indonesia.

Restorasi bermula sebagai gerakan perubahan untuk memperbaiki kondisi (negara, bangsa, dan masyarakat) yang sedang rusak atau menyimpang dari tujuan yang tertuang dalam pembukaan UUD 1945. Istilah ini populer sejak restorasi Meiji di Jepang yang merupakan jawaban bangsa Jepang terhadap demoralisasi dan liberalisasi agar mereka tidak kehilangan karakter dan maju menjadi bangsa yang maju. Gerakan restorasi yang diusung partai Nasdem meletakkan tujuan dan cita-cita dengan menjadikan Pancasila sebagai senjata spiritual, dan rakyat Indonesia sebagai senjata materialnya. Restorasi Indonesia adalah gerakan mengembalikan Indonesia kepada tujuan dan cita-cita Proklamasi 1945, yaitu Indonesia yang berdaulat secara politik, mandiri secara ekonomi, dan berkepribadian secara kebudayaan.

DPD Partai Nasdem Kabupaten Maros merupakan partai pendatang baru di Kabupaten Maros akan tetapi partai ini tidak banyak membutuhkan waktu untuk melakukan pembentukan struktur di setiap kecamatan yang ada. Pada pembentukan struktur kecamatan yang dinamakan Dewan Pimpinan Cabang (DPC) dalam pembentukannya dilakukan secara pendekatan emosional dan 
kekeluargaan dengan mendatangi langsung masyarakat untuk mau bergabung dalam arus besar perubahan sesuai dengan tagline di partai Nasdem restorasi. Di awal pembentukan pengurus pada tingkat Kecamatan atau DPC semua pengurus berasal dari kalangan pemuda dan pemudi bahkan Ketua DPC Kecamatan Bontoa sendiri atas nama Mansyur Muchlis S.pd baru berumur 23 tahun langsung dipercayakan memimpin partai ini di tingkat Kecamatan. Ini menjadi bukti bahwa partai Nasdem semua pengurus yang direkrut $80 \%$ berasal dari kalangan anak muda. Setelah partai dinyatakan lolos oleh Kementrian Hukum dan HAM (Kemenkumham) melalui veripikasi paktual, partai ini sudah bisa mendaftar sebagai peserta pemilu 2014.

Lolosnya Partai Nasdem sebagai peserta pemilu tidak lepas dari peranan dan kerja keras dari pemuda. Namun pada saat Dewan Pimpinan Daerah (DPD) Partai Nasdem diminta oleh KPUD Kabupaten Maros agar secepatnya menyetor daftar nama caleg sementara (DCS) untuk ditetapkan sebagai Daftar Caleg Tetap (DCT) akan tetapi DPD Partai Nasdem tidak bisa menanggapi hal itu karena kondisi partai pada waktu itu mengalami kekosongan Ketua yang ditinggalkan oleh ketua sebelumnya yaitu Hasanuddin S.Kom. Maka pada waktu itu dilakukan musyawarah daerah (Musda) di Hotel Transit II dan terpilihlah $H$. Naharuddin SE sebagai ketua DPD Partai Nasdem yang baru. Pasca terpilihnya Ketua baru, langsung dilakukan penggemukan struktur dengan menambahkan pengurus baru. Ketua DPD Partai Nasdem Kabupaten Maros yang baru berlatar belakang pengusaha bahkan beliau menduduki jabatan sebagai Dirut di PT SEMEN BOSOWA MAROS, otomatis pengurus baru yang di rekrut berasal dari kalangan pengusaha dan kontraktor. Kebijakan yang dikeluarkan Ketua DPD Partai Nasdem Kabupaten Maros dengan merangkul semua teman-teman pengusahanya menimbulkan pro dan kontrak karena kebijakan itu dianggap oleh sebagian pengurus partai ini akan dijadikan kekuatan untuk melindungi para pengusaha. Akan tetapi kisruh ini cepat diredam oleh ketua DPD partai Nasdem Kabupaten Maros dengan alasan bergabungnnya beberapa pengusaha ke partai akan berdampak positif karena Partai akan mendapatkan kekuatan finansial yang kuat lewat para pengusaha itu. Berangkat dari itu penulis tertarik melakukan penelitian mengenai "pola kaderisasi partai Nasdem dalam menghadapi pemilu legislatif 2014 di Kabupaten Maros".

\section{B. KONSEP PARTAI POLITIK}

Almond dalam Sastroatmodjo (1995:115), mengatakan partai politik yang termasuk salah satu kelompok infrastruktur politik adalah partai manusia dimana didalamnya terdapat pembagian tugas dan petugas untuk mencapai suatu tujuan, mempunyai ideologi (Ideal Objective), mempunyai program politik platform, sebagai rencana pelaksanaan atau cara pencapaian tujuan secara lebih pragmatis menurut penahapan jangka dekat sampai yang jangka panjang serta mempunyai ciri berupa keinginan untuk berkuasa. Dengan demikian, setiap partai manusia yang memenuhi kriteria di atas secara material dan substansial dapat dianggap sebagai partai politik.

Partai politik merupakan sarana bagi warga Negara untuk turut serta atau berpartisipasi dalam proses pengelolaan Negara. Menurut Budiarjo (2006:160), partai politik adalah suatu kelompok terorganisir yang anggota-anggotanya mempunyai orientasi, nilai-nilai, dan cita-cita yang sama. Partai politik adalah unsur penting dalam kehidupan politik dan pemerintahan. Partai politik 
menghubungkan masyarakat madani dengan Negara dan lembagalembaganya. Selain itu, partai menyuarakan pandangan serta kepentingan berbagai kalangan masyarakat.

Dalam pasal 1 ayat 1 UU No.2 Tahun 2011 Partai Politik adalah partai yang bersifat nasional dan dibentuk oleh sekelompok warga negara Indonesia secara sukarela atas dasar kesamaan kehendak dan cita-cita untuk memperjuangkan dan membela kepentingan politik anggota, masyarakat, bangsa dan negara, serta memelihara keutuhan Negara Kesatuan Republik Indonesia berdasarkan Pancasila dan Undang-undang Dasar Negara Republik Indonesia Tahun 1945.

Partai politik dapat berarti partai yang mempunyai basis ideologi yang jelas, dimana setiap anggotanya mempunyai pandangan yang sama dan bertujuan untuk merebut kekuasaan atau mempengaruhi kebijaksanaan negara baik secara langsung maupun tidak langsung serta ikut pada sebuah mekanisme pemilihan umum untuk bersaing secara kompetitif guna mendapatkan eksistensi.

Menurut Fiedrich dalam Budiardjo (2006:161), partai politik adalah sekelompok manusia yang terpartai secara stabil dengan tujuan merebut atau mempertahankan penguasaan terhadap pemerintahan bagi pimpinan partainya dan berdasarkan penguasaan ini kemanfaatan yang bersifat idiil maupun materil kepada anggotanya. Menurut Sartori (2000:69), partai politik adalah suatu kelompok politik yang mengikuti pemilihan umum dan melalui pemilihan umum itu mampu menempatkan calonnya untuk menduduki jabatanjabatan.

Partai politik secara ideal dimaksudkan untuk mengaktifkan dan memobilisasi rakyat, mewakili kepentingan tertentu, memberi jalan kompromi bagi pendapat yang saling bersaing, serta menyediakan sarana suksesi kepemimpinan secara absah (legitimate) dan damai.

Berdasarkan beberapa pengertian di atas maka penulis berusaha menggambarkan kembali bahwa partai politik, sesungguhnya adalah kumpulan dari beberapa orang yang mempunyai orientasi sama yang terbentuk dalam suatu wadah lembaga formal berdasar kepada ketentuan konstitusi kelembagaan dan mengikuti sistem politik dan sistem pemilihan yang ada.

Menurut Budiarjo (2000:163), secara hakiki partai politik memiliki fungsi utama yaitu mencari dan mempertahankan kekuasaan guna mewujudkan program-program yang disusun berdasarkan ideologi tertentu. Selain fungsi di atas, partai politik juga memiliki fungsi antara lain: (1) Sebagai sarana komunikasi politik; (2) Sebagai sarana sosialisasi politik; (3) Sebagai sarana rekrutmen politik; (4) Partisipasi politik; dan (5) Sebagai sarana pengatur konflik.

\section{Konsep Rekrutmen Politik}

Rekrutmen politik memegang peranan penting dalam sistem politik suatu Negara karena proses ini menentukan orang-orang yang akan menjalankan fungsi-fungsi sistem politik negara itu melalui lembaga-lembaga yang ada. Oleh karena itu, tercapai tidaknya tujuan suatu sistem politik tergantung pada kualitas rekrutmen politik. Menurut Noeat (2012:20), rekrutmen didefinisikan sebagai pelaksanaan atau aktifitas partai awal dengan tujuan untuk mengidentifikasi dan mencari tenaga kerja yang potensial.

Menurut Surbakti (1999:25), rekrutmen politik mencakup pemilihan, seleksi, dan pengangkatan seseorang atau sekelompok orang untuk melaksanakan sejumlah peranan dalam 
sistem politik pada umumnya dan pemerintahan pada khususnya. Partai politik memiliki cara tersendiri dalam melakukan rekrutmen terutama dalam pelaksanaan sistem dan prosedural rekrutmen yang dilakukan partai politik tersebut. Tak hanya itu proses rekrutmen juga merupakan fungsi mencari dan mengajak orang-orang yang memiliki kemampuan untuk turut aktif dalam kegiatan politik, yaitu dengan cara menempuh berbagai proses penjaringan.

Suharno dalam Syafie (2009:58), menyatakan rekrutmen politik adalah proses pengisian jabatan-jabatan pada lembaga-lembaga politik, termasuk partai politik dan administrasi atau birokrasi oleh orang-orang yang akan menjalankan kekuasaan politik.

Teori Rekrutmen menurut Almond dan Powell dalam Prihatmoko (2005:200), rekrutmen politik adalah suatu proses dimana terjadi penseleksian calon-calon masyarakat yang dipilih untuk menempati kursi-kursi penting di dalam peranan politik, termasuk dalam jabatan birokrasi dan jabatan administrasi.

2. Konsep Institusionalisasi Partai

Rahman (1998:67), mengemukakan bahwa Institusional partai memandang partai politik sebagai lembaga yang memiliki struktur dan fungsi untuk mencapai tujuan. Teori kelembagaan (Institusional), yang menyatakan bahwa partai politik dibentuk oleh lembagalembaga negara baik legislatif maupun eksekutif sebagai kebutuhan para anggotanya untuk mengadakan kontak dan membina dukungan dengan masyarakat. Hal ini dilakukan agar kebijakan-kebijakan yang dihasilkan tidak bisa dengan kebutuhan, tuntutan, dan harapan publiknya. Sehingga dibuatlah wadah yang mampu menampung aspirasi warga masyarakat yang kemudian dikenal dengan istilah partai politik.
Partai politik adalah partai yang mempunyai fungsi sebagai penyalur artikulasi dan agregasi kepentingan publik yang paling mapan dalam sebuah sistem politik modern. Menurut Michels (1984:23), secara sederhana partai politik merupakan representation of ideas yang harus ada dalam kehidupan politik modern yang demokrasi. Partai politik sebagai suatu partai yang berorientasi pada representation of ideas secara ideal dimaksudkan untuk mewakili kepentingan-kepentingan warga, memberikan jalan kompromi bagi pendapat/tuntutan yang saling bersaing, serta menyediakan ruang bagi suksesi kepemimpinan politik secara damai dan legitimasi.

3. Konsep Pemilu Legislatif

Pemilu singkatan dari Pemilihan Umum. Sedangkan legislatif adalah lembaga perwakilan rakyat yang fungsi utamanya membuat Undang-undang atau peraturan, yang anggotanya terdiri dari orang-orang pilihan dan terpilih. Di Indonesia badan legislatif ini disebut Dewan Perwakilan Rakyat, disingkat DPR. Untuk tingkat Kabupaten atau Kotamadya disebut Dewan Perwakilan Rakyat Daerah, disingkat DPRD Demikian pula untuk di tingkat Provinsi disebut DPRD Propinsi. Sedangkan untuk di Pusat disebut DPR. Jadi kalau di sebut DPR saja tanpa tambahan Propinsi atau Kabupaten itu berarti DPR Pusat. Anggota DPR/DPRD ini mewakili seluruh kepentingan atau golongan yang ada di Indonesia. Jadi Pemilu Legislatif adalah pemilihan umum yang diselengarakan secara serempak untuk memilih wakil-wakil rakyat yang akan duduk di DPR. Mengenai kenapa serempak, lebih dititikberatkan untuk mengurangi pemilih yang memilih diberbagai daerah diluar Kabupaten atau Kotamadya dimana ia berdomisili, sehingga kemungkinan seorang pemilih 
memilih lebih dari satu kali dapat diminimalisir.

Pemilihan umum diikuti oleh partai-partai politik. Partai-partai politik mewakili kepentingan spesifik warga negara. Kepentingan-kepentingan seperti nilai-nilai agama, keadilan, kesejahteraan, nasionalisme, anti korupsi, dan sejenisnya kerap dibawakan partai politik tatkala mereka berkampanye. Sebab itu, sistem pemilihan umum yang baik adalah sistem yang mampu mengakomodasi kepentingan-kepentingan yang berbeda di tingkat masyarakat, agar terwakili dalam proses pembuatan kebijakan negara di parlemen.

\section{METODE PENELITIAN}

Jenis penelitian yang digunakan peneliti dalam penelitian ini adalah metode kualitatif. Metode kualitatif memiliki beberapa prespektif teori yang dapat mendukung penganalisaan yang lebih mendalam terhadap gejala yang terjadi, dikarenakan kajiannya adalah fenomena masyarakat yang selalu mengalami perubahan (dinamis). Tipe Penelitian yang digunakan peneliti dalam penelitian ini adalah deskriptif analisis yaitu penelitian diarahkan untuk menggambarkan fakta dengan argument yang tepat.

Sumber data yang digunakan yaitu Data Primer, dalam penelitian ini peneliti telah mencari data untuk membuktikan fakta di lapangan. Data yang diperoleh melalui lapangan atau daerah penelitian dari hasil wawancara mendalam dengan informal dan observasi langsung. Data Sekunder, dalam penelitian peneliti juga melakukan telaah pustaka, di mana peneliti mengumpulkan data dari penelitian sebelumnya berupa buku, jurnal, koran mengenai Partai Nasdem Kabupaten Maros dan pola rekrutmen politik Partai Nasdem dalam proses intitusional partai, serta sumber informasi lainnya yang berkaitan dengan masalah penelitian ini.

Analisis data dilakukan melalui tiga alur yakni: Reduksi data, pada tahap ini dilakukan proses penyeleksian, pemfokusan, penyederhanaan, pengabstraksian data dari catatan lapangan (field note). Sajian data, sajian data adalah suatu susunan informasi yang memungkinkan kesimpulan penelitian dapat dilakukan.

\section{HASIL DAN PEMBAHASAN}

\section{Profil DPD Partai Nasdem Kabupaten Maros}

Partai Nasdem Maros yang didirikan oleh beberapa orang pemuda yang berasal dari beberapa mantan aktivis organisasi daerah yang bernama Himpunan Pemuda Mahasiswa Indonesia (HIPMI) Maros Raya dan HPPMI Maros. Salah satu pendiri Partai Nasdem Maros adalah Abrar Rahman SS yang pernah menjabat sebagai Ketua umum ke II Pengurus Besar di Hipmi Maros Raya periode 2010-2012 dan sekarang menjadi Ketua Badan Pemenangan Pemilu (Bappilu) Kabupaten Maros. Berdirinya Partai Nasdem Maros tidak lepas dari peranan pemuda yang berasal dari perguruan tinggi yang ada di Makassar yang tergabung dalam organisasi daerah yang ada di Kabupaten Maros. Pemuda inilah yang menjadi perintis sekaligus pendiri DPD Partai Nasdem Kabupaten Maros.

Sejarah singkat berdirinya Partai Nasdem Kabupaten Maros ini dipelopori oleh kaum muda yang sudah matang di organisasi. Orang yang pertama kali yang membawa Partai Nasdem ke Kabupaten Maros adalah Sanusi Ramadhan yang menjabat pada waktu itu sebagai Ketua Dewan Pimpinan Wilayah (DPW) Sul-Sel. Pada waktu beliau membawa Partai Nasdem ke Kabupaten Maros, partai ini di tawarkan kepada juniornya sendiri sewaktu bergelut di lembaga 
kemahasiswaan di Ikatan Mahasiswa Muhammadiyah sewaktu menjadi aktivis kampus yang bernama Hasanuddin Usman.

Pada pertemuan perdana untuk membahas pembentukan awal Dewan Pimpinan Daerah (DPD) Partai Nasdem Kabupaten Maros ini berlangsung di Cafe Buana Maros yang bertempat di Maros kota tepat samping kiri masjid besar Almarkas Maros. Dari pertemuan itu dihadiri oleh beberapa aktivis mahasiswa dari berbagai daerah yaitu Abrar Rachman S.S dan Ratnawati dari Himpunan Pemuda Mahasiswa Indonesia (HIPMI) Maros Raya, Nelwan Beno dari Himpunan Pelajar Pemuda Mahasiswa Maros (HPPMI Maros), Abd Haris S.Pd.i dan Firda Handayani dari Pergerakan Mahasiswa Islam Indonesia (PMII) Cabang Maros, Nursyam S.Pd, Hasanuddin Usman S.Kom, dan Akmal S.Kom dari Ikatan Mahasiswa Muhammadiyah (IMM).

Lewat pertemuan itu mereka sepakat bersama-sama untuk mendirikan DPD Partai Nasdem Kabupaten Maros. Tidak lama berselang kemudian pertemuan itu ditindak lanjuti dengan melakukan pertemuan selanjutnya dengan membahas tempat dimana akan dideklarasikan Dewan Pimpinan Daerah Partai Nasdem Kabupaten Maros sekaligus pembentukan struktur pengurus partai. Setiap partai politik memiliki visi misi sebagai pijakan dalam menajalankan tanggung jawab mereka, adapun visi partai Nasdem adalah: "Indonesia yang merdeka sebagai negara bangsa, berdaulat secara ekonomi, dan bermartabat dalam budaya". Dan misi partai Nasdem antara lain:

a) Membangun Politik Demokratis berkeadilan berarti menciptakan tata ulang demokrasi yang membuka partisipasi politik rakyat dengan cara membuka akses masyarakat secara keseluruhan. Mengembangkan model pendidikan kewarganegaraan untuk memperkuat karakter bangsa, serta melakukan perubahan menuju efisiensi sistem pemilihan umum. Memantapkan reformasi birokrasi untuk menciptakan sistem pelayanan masyarakat. Melakukan reformasi hukum dengan menjadikan konstitusi UUD 1945 sebagai kontrak politik kebangsaan;

b) Menciptakan Demokrasi Ekonomi. Melalui tatanan demokrasi ekonomi maka tercipta partisipasi dan akses masyarakat dalam kehidupan ekonomi negara, termasuk di dalamnya ditribusi ekonomi yang adil dan merata yang akan berjuang pada kesejahteraan seluruh rakyat Indonesia. Dalam mewujudkan citacita ini maka perlu untuk mendorong penciptaan lapangan kerja, sistem jaminan sosial nasional, penguatan industri nasional, serta mendorong kemandirian ekonomi di level lokal;

c) Menjadikan budaya gotong royong sebagai karakter bangsa.

Selanjutnya partai Nasdem bertujuan mewujudkan masyarakat yang demokratis, berkeadilan, dan berkedaulatan. Dengan semangat kebangsaan partai berfungsi untuk:

a) Memperkuat kedaulatan dan keutuhan Negara Kesatuan dan keutuhan Negara Kesatuan Republik Indonesia;

b) Mewujudkan negara kesejahteraan sesuai mandat konsistusi;

c) Mengembangkan kehidupan politik kebangsaan yang demokratis, partisipatif, dan beradab;

d) Menciptakan tatanan perekonomian dengan prinsip demokrasi ekonomi;

e) Menegakkan keadilan sosial dan kedaulatan hukum;

f) Memenuhi hak asasi manusia dan hak warga Negara Indonesia;

g) Mengembangkan kepribadian bangsa yang luhur dan kehidupan sosial- 
budaya yang egaliter berdasarkan prinsip Bhineka Tunggal Ika.

\section{Pola Rekrutmen Politik Legislatif Partai Nasdem Kabupaten Maros Pada Pemilu 2014}

Rekrutmen politik atau representasi politik memegang peranan penting dalam sistem politik suatu negara. Karena proses ini menentukan orang-orang yang akan menjalankan fungsi-fungsi sistem politik negara itu melalui lembaga-lembaga yang ada. Rekrutmen politik diatur dalam UU No. 2 Tahun 2011 pasal 29 ayat 1 yang berbunyi "Partai politik melakukan Rekrutmen terhadap warga negara Indonesia untuk menjadi anggota partai politik, bakal calon anggota Dewan Perwakilan Rakyat dan Dewan Perwakilan Rakyat Daerah, bakal calon Presiden dan Wakil Presiden, dan calon Kepala Daerah dan Wakil Kepala Daerah. Oleh karena itu, tercapai tidaknya tujuan suatu sistem politik yang baik tergantung pada kualitas rekrutmen politik. Kehadiran suatu partai politik dapat dilihat dari kemampuan partai tersebut melaksanakan fungsinya. Salah satu fungsi yang terpenting yang dimiliki partai politik adalah fungsi rekrutmen politik. Sehubungan dengan hal tersebut informan dengan inisial HN selaku Ketua DPD Partai Nasdem Kabupaten Maros mengatakan:

"Rekrutmen Politik atau representasi politik memegang peranan penting dalam sistem politik suatu negara. Hal ini dikarenakan proses ini menentukan siapa sajakah yang akan menjalankan fungsi-fungsi sistem politik negara itu melalui lembaga-lembaga yang ada. Oleh karena itu, tercapai tidaknya tujuan suatu sistem politik yang baik tergantung pada kualitas rekrutmen politik". (wawancara $H N)$

Hal ini menunjukkan rekruitmen politik memiliki peranan penting dalam menjalankan fungsi-fungsi sistem politik di negara ini, karena sistem politik baik ditentukan oleh kualitas daripada rekrutmen politik. fakta di lapangan menunjukkan rekrutmen politik terkadang dianggap gampang oleh segelintir pengurus partai dalam menjalankan rekrutmen itu, sementara rekrutmen itu merupakan pintu gerbang yang harus dilalui oleh semua masyarakat yang ingin bergelut dalam dunia politik maka dari itu rekrutmen politik harus dijalankan sebaik mungkin bukan sekedar untuk menggugurkan tanggung jawab.

Setiap partai politik memiliki pola rekrutmen yang berbeda, di mana pola perekrutan anggota partai disesuaikan dengan sistem politik yang dianut. Rekrutmen keanggotaan Partai Nasdem sudah diatur dalam AD/RT Partai, terkait dengan hal tersebut informan dengan inisial AH selaku Wakil Ketua DPD Partai Nasdem Kabupaten Maros mengatakan :

"Rekrutmen Politik Partai Nadem Kabupaten Maros semuanya sudah diatur dalam AD/RT Partai Nasdem, baik itu Rekrutmen calon anggota legislatif maupun calon." (wawancara AH)

Pernyataan ini sangat jelas bahwa sebuah partai politik tanpa rekrutmen atau anggota tidak berarti apa-apa, karena partai dibangun atas tiga hal, yaitu ideologi/struktur, anggota, dan sumber dana. Regenerasi partai ke depan akan baik jika proses perekrutan anggota sistematis dan ditangani secara profesional. Keanggotaan di sini juga sebagai basis massa dan juga sebagai kekuatan partai dalam mempertahankan eksistensinya. Rekrutmen akan berjalan baik jika pihak-pihak terkait saling membantu dan bekerja sama 
membentuk pola pengkaderan. Dikatakan rekrutmen itu berhasil apabila dari proses rekrutmen tersebut dalam menciptakan pribadi yang tangguh dan memiliki loyalitas yang tinggi terhadap partai.

Sehubungan dengan hal tersebut informan dengan inisial SA selaku Sekertaris Umum DPD Partai Nasdem Kabupaten Maros mengatakan :

"Rekrutmen politik merupakan proses seleksi anggota-aggota kelompok untuk mewakili kelompoknya dalam jabatan administratif maupun politik. Dalam pengertian lain, rekrutmen politik merupakan fungsi penyeleksian rakyat untuk kegiatan politik dan jabatan pemerintahan melalui penampilan dalam media komunikasi, menjadi anggota partai, mencalonkan diri untuk jabatan tertentu dan sebagainya". (wawancara SA)

Rekrutmen politik harus konsisten pada mekanisme perekrutan karena hasil dari rekrutmen itu merupakan orangorang yang akan memikul tanggung jawab besar baik di partai dan pemerintahan. Sehubungan dengan hal tersebut informan dengan inisial AR selaku Ketua Bappilu DPD Partai Nasdem Kabupaten Maros mengatakan :

"Rekrutmen Politik mencakup pemilihan, seleksi, dan pengangkatan seseorang atau sekelompok orang untuk melaksanakan sejumlah peranan dalam sistem politik pada umumnya dan pemerintah pada khususnya. Untuk itu partai politik memiliki cara tersendiri dalam melakukan pengrekrutan terutama dalam pelaksanaan sistem dan prosedural pengrekrutan yang dilakukan

\section{partai politik tersebut ". (wawancara AR)}

Proses pemilihan, penyeleksian, serta pengangkatan seseorang atau sekelompok orang untuk melaksanakan sejumlah peranan dalam sistem politik pada umumnya dan pemerintah pada khususnya. Sehingga rekrutmen politik memegang peranan penting dalam sistem politik suatu Negara olehnya itu pola rekrutmen yang di digunakan oleh setiap partai harus dijalankan secara profesional supaya hasil yang di dapatkan dari rekrutmen itu adalah orang-orang profesional pula.

Rekrutmen politik terbuka mengandung makna bahwa semua warga Negara yang memenuhi syarat-syarat yang ditentukan serta mempunyai bakat, tanpa kecuali mempunyai kesempatan yang sama untuk menduduki jabatan politik maupun jabatan pemerintahan. Pelaksanaan proses rekrutmen politik di ranah kekuasaan legislatif atau dengan kata lain adalah perekrutan calon anggota legislatif, Partai Nasdem Kabupaten Maros memiliki pola rekrutmen yaitu Pola rekrutmen terbuka karena beberapa alasan.

Pola rekrutmen yang dijalankan oleh Partai Nasdem Kabupaten Maros adalah Pola rekrutmen terbuka. Artinya Partai Nasdem Kabupaten Maros menggunakan rekrutmen terbuka (Open recruitment) yang sangat terbuka untuk calon anggota legislatif, sehingga secara langsung pola seperti ini memberikan kesempatan yang sangat luas bagi siapapun anggota masyarakat yang ingin mendaftarkan diri sebagai calon anggota legislatif dari Partai Nasdem Kabupaten Maros, walaupun seseorang itu bukan kader atau pengurus Partai Nasdem Kabupaten Maros akan tetapi terbuka kesempatan buat mereka yang ingin mendaftarkan dirinya sebagai calon anggota legislatif asalkan dapat memenuhi syarat-syarat yang berlaku 
dan betul-betul ingin berjuang untuk memenangkan partai dalam pemilu bukan sekedar numpang nama yang hanya mencari popularitas saja.

\section{Langkah-Langkah yang ditempuh Partai Nasdem dalam Rekrutmen Politik di Kabupaten Maros}

Rekrutmen merupakan hal penting bagi sebuah partai, karena merupakan inti dari kelanjutan perjuangan partai ke depan. Tanpa rekrutmen, rasanya sangat sulit dibayangkan sebuah partai dapat bergerak dan melakukan tugas-tugas kepartaiannya dengan baik dan dinamis. Rekrutmen adalah sebuah keniscayaan mutlak membangun struktur kerja yang mandiri dan berkelanjutan. Rekrutmen politik memegang peranan penting dalam sistem politik suatu Negara karena proses ini menentukan orang-orang yang akan menjalankan fungsi-fungsi sistem politik negara itu melalui lembagalembaga yang ada. Adapun langkahlangkah yang dilakukan oleh DPD Partai Nasdem Kabupaten Maros yaitu sebagai berikut:

1) Membentuk Tim Seleksi Rekrutmen

Pada tahap ini yaitu pembentukan tim seleksi rekrutmen yang dihadiri oleh semua pengurus baik pengurus Kabupaten maupun pengurus Kecamatan untuk membentuk tim seleksi rekrutmen. Tim seleksi rekrutmen terbentuk dengan adanya musyawarah antar pengurus, lewat musyawarah ini akan muncul kesepakatan siapa yang akan masuk dalam tim seleksi rekrutmen calon legislatif DPD Partai Nasdem Kabupaten Maros. Karena ketua tim seleksi langsung di komandoi oleh Ketua Umum DPD Partai Nasdem Maros dengan Ketua Bappilu DPD Partai Nasdem Kabupaten Maros.

Terkait dengan hal tersebut diatas informan dengan inisial HN selaku Ketua DPD Partai Nasdem Kabupaten Maros menyatakan bahwa:

"Tim seleksi rekrutmen
merupakan komponen paling
penting dalam melaksanakan
rekrutmen politik karena tim
seleksilah yang bertanggung
jawab penuh dalam hal
rekrutmen calon anggota
legislatif". (Wawancara HN)

Tim seleksi rekrutmen merupakan komponen dari proses rekrutmen yang sangat penting yang tidak bisa dipisahkan. Selanjutnya tim seleksi menentukan hasil dari proses rekrutmen, berhasil tidaknya partai melakukan regenarasi kepemimpinan ditentukan oleh tim seleksi maka dari itu tim seleksi ini harus diisi oleh orang- orang yang mempunyai kapabilitas serta karakter yang menjunjung tinggi profesionalisme.

2) Syarat dan prosedur diumumkan secara luas

Menurut Surbakti, bahwa rekrutmen politik mencakup pemilihan, seleksi, dan pengangkatan seseorang atau sekelompok orang untuk melaksanakan sejumlah peranan dalam sistem politik pada umumnya dan pemerintah pada khususnya. Partai politik memiliki cara tersendiri dalam melakukan rekrutmen terutama dalam pelaksanaan sistem dan prosedural rekrutmen yang dilakukan partai politik tersebut, yaitu dengan cara menempuh berbagai proses sosialisasi persyaratan dan penjaringan.

3) Liberalisasi politik terhadap kader partai

Rekrutmen anggota Partai Nasdem dilakukan dengan cara persuasif yang diawali dengan sosialisasi partai kepada masyarakat Kabupaten Maros untuk menampilkan eksistensi partai dalam menghadapi pemilu 2014. Bagi masyarakat yang ingin bergabung menjadi anggota caranya cukup mudah, hanya mengisi formulir keanggotaan serta menyertakan fotokopi Kartu Tanda Penduduk (KTP) dan kemudian akan 
dibuatkan Kartu Tanda Anggota (KTA) Partai Nasdem Kabupaten Maros. Sedangkan, implementasi rekrutmen calon anggota legislatif dilakukan melalui tahap penjaringan, tahap penyaringan, dan tahap penetapan berdasarkan syarat-syarat yang telah diberlakukan.

Berdasarkan sistem yang digunakan dalam rekrutmen politik partai ini. yaitu sistem rekrutmen politik terbuka yang digunakan dalam penerimaan kader partai. Penerimaan kader partai ini bersifat terbuka, artinya tidak memandang status, kedudukan, kekayaan, jabatan dan lain-lain. Penerimaan kader ini di awali dengan pengisian surat pernyataan anggota Partai Nasdem disertai fotocopy data diri seperti KTP, SIM atau KTM bagi mahasiswa.. Berkas tersebut kemudian diserahkan ke DPC, DPD, atau DPW Partai Nasdem. Setelah berkas diterima, pihak partai kemudian akan mengirimkan data ke DPP. Pengiriman data yang dilakukan secara online ini bertujuan untuk mendapatkan KTA partai dari DPP. Untuk menarik minat anggota, partai Nasdem memberi beberapa iming-iming asuransi sebesar satu juta yang berlaku bila telah menjadi anggota partai.

Fungsi dari rekrutmen adalah mempersiapkan calon-calon (embrio) yang siap melanjutkan tongkat estafet perjuangan sebuah partai. Kader suatu partai adalah orang yang telah dilatih dan dipersiapkan dengan berbagai keterampilan dan disiplin ilmu, sehingga dia memiliki kemampuan yang di atas rata-rata orang umum. Surya paloh pernah menyatakan rekrutmen dalam kerangka kebangsaan, "Bahwa rekrutmen sama artinya dengan menanam bibit. Untuk menghasilkan pemimpin bangsa di masa depan, pemimpin pada masanya harus menanam".
Maka dari sinilah pandangan umum mengenai rekrutmen suatu partai dapat dipetakan menjadi dua ikon secara umum. Pertama, pelaku rekrutmen (subyek) dan kedua, sasaran rekrutmen (obyek). Untuk yang pertama, subyek atau pelaku rekrutmen sebuah partai adalah individu atau sekelompok orang yang dipersonifikasikan dalam sebuah partai dan kebijakan-kebijakannya yang melakukan fungsi regenerasi dan kesinambungan tugas-tugas partai. Sedangkan yang kedua adalah obyek dari rekrutmen, dengan pengertian lain adalah individu-individu yang dipersiapkan dan dilatih untuk meneruskan visi dan misi partai. Sifat sebagai subyek dan obyek dari proses rekrutmen ini sejatinya harus memenuhi beberapa fondasi dasar dalam pembentukan dan pembinaan kaderkader partai yang handal, cerdas dan matang secara intelektual dan psikologis.

Setiap partai politik dalam mengusulkan calon anggota legislatif harus memiliki kemampuan yang dapat menunjang tugas pokok anggota DPR bukan sekedar hanya memiliki tingkat popularitas yang di andalkan untuk mendulang suara. Sebelum mengusulkan calon anggota legislatif, parpol terlebih dahulu memberikan bimbingan tekhnik supaya calon anggota legislatif yang akan maju bertarung dalam percaturan pemilihan umum mempunyai bekal dan pengetahuan tentang tugas pokok dan fungsi anggota legislatif. Sehubungan dengan hal tersebut informan dengan inisial AM selaku calon anggota legislatif DPD Partai Nasdem Kabupaten Maros mengatakan :

"Calon anggota legislatif yang sudah direkrut oleh setiap dewan pimpinan daerah ( DPD) di seluruh dewan pimpinan wilayah $(D P W)$ di Indonesia wajib mengikuti bimbingan tekhnik yang di selengarakan oleh dewan 
pimpinan wilayah (DPW) sebanyak dua kali". (wawancara $A M)$

DPD Partai Nasdem di setiap daerah telah mengikuti bimbingan tekhnik (bimtek) karena bimtek ini menjadi keharusan bagi setiap calon anggota legislatif Partai Nasdem di seluruh Indonesia. Pemberian bimbingan tekhnik (Bimtek) yang dilakukan oleh Partai Nasdem sangat efektif karena dari sekian banyaknya anggota legislatif yang ada saat ini masih ada yang tidak tau membedakan instruksi dengan interupsi, fenomena ini sangat mengerihkan bagaimana dia menjalankan tugas pokok dan fungsi sebagai anggota legislatif ketika hal yang kecil saja tidak bisa di jelaskan.

Kaderisasi kepemimpinan di partai politik merupakan salah satu fungsi penting yang seharusnya mendapat prioritas karena partai politik masih menjadi saluran utama rekrutmen kepemimpinan di daerah dan nasional. Suatu partai politik yang terinstitusionalisasi dengan baik, tentunya akan dapat mengembangkan kapasitas untuk rekrutmen dan kaderisasi sehingga partai politik dapat menjadi penyumbang tokoh-tokoh handal pemimpin. Sehubungan dengan hal tersebut informan dengan inisial HN selaku Ketua DPD Partai Nasdem Kabupaten Maros mengatakan :

"Kegagalan partai politik dalam rekrutmen kepemimpinan memang tidak serta merta kesalahan partai politik sendiri. Regulasi, sistem kepartaian, sistem pemilu, dan rezim pemerintahan turut menyumbang bagi kemunduran fungsi penting partai politik ini. Selain itu, masyarakat yang sudah apatis dengan janji-janji muluk juga semakin terbuai dengan aksi-aksi pencitraan karena hanya pada saat pemilihan berlangsung pemilih dapat mendapatkan sesuatu secara langsung dari para kandidat yang bertarung". (wawancara $H N$ )

Partai politik memiliki peranan penting dalam melahirkan calon pemimpin yang berkualitas, dan melahirkan pula calon pemimpin yang tidak berkualitas karena partai politik menjadi agen rekrutmen kader yang nantinya akan menjadi pemimpin di masa yang akan datang. Maka dari itu sistem kepartaian harus di perbaiki supaya orang-orang yang tergabung dalam partai politik mengerti cita-cita dari partai politik. Partai politik harus profesional dan terbuka dalam melakukan rekrutmen bukan hanya sekedar formalitas melakukan rekrutmen kader karena kader-kader yang telah di rekrut bergabung dalam partai politik adalah orang-orang yang akan dinominasikan dalam pesta demokrasi yang nantinya akan menjadi pemegang kebijakan dalam pemerintahan.

\section{E. PENUTUP}

Berdasarkan hasil pembahasan terkait DPD Partai Nasdem Kabupaten Maros dalam hal pola kaderisasi calon anggota legislatif yang di gunakan adalah:

1. Pola Rekrutmen calon anggota legislatif yang digunakan pada DPD Partai Nasdem Kabupaten Maros adalah Pola rekrutmen terbuka, yaitu memberikan kesempatan yang sangat luas bagi siapapun anggota masyarakat yang ingin mendaftarkan diri sebagai calon anggota legislatif dari Partai Nasdem Kabupaten Maros, walaupun seseorang itu bukan kader atau pengurus partai asal dapat memenuhi syarat-syarat dan ketentuan yang berlaku. 
2. Langkah-langkah yang ditempuh Partai Nasdem Kabupaten Maros yang mampu memudahkan dalam proses perekrutan yaitu: membentuk tim seleksi rekrutmen, syarat dan prosedur diumumkan secara luas, dan memberi peluang yang sama.

\section{DAFTAR PUSTAKA}

Budiarjo, Miriam. 2006. Dasar-Dasar Ilmu Politik, Jakarta: Gramedia Pustaka Utama

Ichlasul, Amal. 1998. Teori-teori mutakhir Partai, Yogyakarta: PT. Tiara Wacana

Michels, Robert. 1984. Partai Politik: Kecenderungan Oligarkis dalam Birokrsi, Jakarta: Rajawali

Miles, Mathew \& Huberman, Michael. 1995. Analisa data kualitatif, Jakarta: UI Press

Okezone, News. 2011. Tiga Langkah Partai Nasdem Setelah Lolos Verifikasi, diakses tanggal 22 Januari 2014. Http://News.Okezone.Com

Pamungkas, Sigit. 2009. Pengertian Parpol dan Asal usul, diakses tanggal $22 \quad$ Januari 2015. Http:///www.scribd.com

Prihatmoko, Joko J. 2005. Pemilihan Kepala Daerah Langsung, Semarang: Pustaka Pelajar

Rahman, Arifin. 1998. Sistem Politik Indonesia, Surabaya: LPM IKIP

Sastroatmodjo, Sudijono. 1995. Perilaku Politik, Semarang: IKIP Semarang Press

Satria, Bambang. 2008. Rekrutmen Politik dan Kader Loncat Katak, diakses tanggal 22 Januari 2015. Http://www.radarbangka.Co.id
Sugiarto, Arya. 2008. Partai Politik dan Prospek, diakses tanggal 22 Januari 2015.

Http://Bimaaryasugiarto.Blogspot. Com

Surbakti, Ramlan. 2010. Memahami Ilmu Politik, Jakarta: PT. Grasindo

Syafie, Inu Kencana. 2009. Pengantar Ilmu Politik, Bandung:Pustaka Reka Cipta

Dokumen :

Undang-Undang Nomor 2 Tahun 2011 pasal 29 ayat 1 tentang Rekrutmen Politik. 